\author{
Jolanta RUBIK ${ }^{1}$ \\ Lukasz SZYDEKKO ${ }^{2}$
}

\title{
RAPORTY CSR A EMPLOYER BRANDING
}

Celem artykułu jest wskazanie znaczenia raportowania niefinansowego jako istotnej przesłanki dla budowania strategii marki pracodawcy. Zarządzanie przedsiębiorstwem to nastawienie na zysk, rozwój i wartość. Do osiągnięcia tych celów firmy mają do dyspozycji zasoby rzeczowe, finansowe i ludzkie. Priorytety mogą być różne i nie do podważenia jest duże znaczenie każdego z tych zasobów. Artykuł zajmuje się obszarem kapitału ludzkiego, jakim są pracownicy. Rynek pracy przechodzi od kilku lat rewolucję w kierunku rynku pracownika, co oznacza, że coraz częściej i odważniej to kandydaci do pracy dyktują swoje warunki lub przynajmniej mają określone wymagania i oczekiwania wobec nowej pracy. Dostosowując się do zmian, przedsiębiorstwa w obszarach HR tworzą strategię budowania wizerunku i marki pracodawcy, skierowaną do potencjalnych i obecnych pracowników - tzw. employer branding. W połączeniu z zastosowaniem koncepcji społecznej odpowiedzialności biznesu (CSR, corporate social responsibility) i raportowaniem niefinansowym jest to sposób na znalezienie się w czołówce najlepszych pracodawców, ale również na uzyskanie przewagi konkurencyjnej na rynku, co nie pozostaje bez wpływu na wyniki finansowe. Raporty CSR mogą wspomóc firmę w budowaniu wizerunku na zewnątrz przez przekazywanie wiarygodnej, rzetelnej informacji interesariuszom i tworzenie podstaw dialogu z nimi oraz budowanie przejrzystych, trwałych relacji. W pracy posłużono się analizą literatury, raportów i przykładami praktycznymi funkcjonującymi w polskiej rzeczywistości gospodarczej, jak również obserwacjami własnymi.

Słowa kluczowe: budowanie marki pracodawcy, employer branding, corporate social responsibility, raportowanie niefinansowe

\section{WPROWADZENIE}

Zarządzanie kapitałem ludzkim jest obecnie sprawą nie tylko komórek HR, ale także całego managementu. Pozyskanie i utrzymanie wartościowych pracowników stosunkowo niedawno zaczęło być traktowane jako niezbędny element strategii przedsiębiorstwa, koniecznością bowiem staje się dziś scalenie strategii personalnej z ogólną strategią firm. Uwzględnienie w tej strategii idei społecznej odpowiedzialności biznesu (CSR, corporate social responsibility) jest warunkiem sine qua non funkcjonowania przedsiębiorstwa. Obecnie raportowanie CSR wynika nie z prawnego obowiązku, lecz z przekonania przedsiębiorstw o konieczności, z punktu widzenia wizerunku firmy, pozostania konkurencyjnymi na rynku, jak również jest postrzegane jako istotne w kontekście redukcji kosztów oraz nowych możliwości biznesowych ${ }^{3}$. Dlatego odgrywa coraz większą rolę w ujęciu

\footnotetext{
${ }^{1}$ Dr Jolanta Rubik, Instytut Finansów, Bankowości i Rachunkowości, Wydział Zarządzania, Politechnika Częstochowska, ul. Armii Krajowej 19b, 42-200 Częstochowa, e-mail: rubik@zim.pcz.pl

${ }^{2}$ Dr Łukasz Szydełko, Zakład Finansów, Bankowości i Rachunkowości, Wydział Zarządzania, Politechnika Rzeszowska, al. Powstańców Warszawy 8, 35-959 Rzeszów, e-mail: lukaszsz@prz.edu.pl

3 J. Kaputa, Raportowanie zrównoważonego rozwoju jako wyzwanie dla przedsiębiorstw XXI wieku, „Zarządzanie i Finanse” 11/1 (2013), s. 113-127, http://jmf.wzr.pl/pim/2013_1_2_8.pdf (dostęp: 10.02.2016).
} 
globalnym jako element idei zrównoważonego rozwoju, w ujęciu lokalnym zaś jako informacja dla interesariuszy, uzupełnienie sprawozdania finansowego o informacje niefinansowe. To właśnie takie informacje stają się coraz ważniejsze między innymi na rynku pracy. Raporty niefinansowe dotyczą głównie trzech obszarów: ochrony środowiska, spraw społecznych oraz ładu korporacyjnego i są w połączeniu ze sprawozdaniami finansowymi niezbędnym elementem sprawozdań zintegrowanych. Dane niefinansowe są w tym kontekście ważniejsze od danych finansowych, które z definicji i z konieczności dotyczą historii, natomiast osoby wchodzące na rynek pracy są zainteresowane teraźniejszością przedsiębiorstwa oraz jego ofertą dotyczącą przyszłości i perspektywami dla potencjalnego pracownika. Budowanie marki pracodawcy podparte dobrymi praktykami z zakresu CSR staje się ważnym aspektem funkcjonowania przedsiębiorstw. Celem artykułu jest wskazanie znaczenia raportowania niefinansowego jako istotnej przesłanki dla budowania strategii marki pracodawcy. W połączeniu z zastosowaniem koncepcji CSR i raportowaniem niefinansowym jest to sposób na znalezienie się w czołówce najlepszych pracodawców i uzyskanie przewagi konkurencyjnej na rynku, co nie pozostaje bez wpływu na wyniki finansowe. Raporty CSR mogą wspomóc firmę w budowaniu wizerunku na zewnątrz przez przekazywanie wiarygodnej, rzetelnej informacji interesariuszom i tworzenie podstaw dialogu z nimi oraz budowanie przejrzystych, trwałych relacji.

\section{CZYM JEST EMPLOYER BRANDING?}

Employer branding (EB), czyli świadome budowanie wizerunku pracodawcy, to połączenie działań HR z marketingowymi, skierowanymi zarówno na zewnątrz - do potencjalnych kandydatów, jak i do wewnątrz - do własnych pracowników. To pracownicy są najlepszymi ambasadorami firmy, a ich pozytywna opinia jest najlepszą wizytówką jednostki na zewnątrz ${ }^{4}$.

W związku ze zmianą rynku pracodawcy na rynek pracownika firmy powinny włączyć zjawisko employer brandingu do swojej strategii, ponieważ „w celu zmaksymalizowania przewagi konkurencyjnej firma musi dostosować swoje zasoby i możliwości do szans dostępnych na rynku zewnętrznym"5.

Badanie Employer Branding w Polsce, przeprowadzane przez HRM Institute ${ }^{6}$, wykazuje między innymi czynniki wpływające na biznes w Polsce, wśród których znaczący spadek znaczenia wykazują w latach 2013-2016 kwestie gospodarcze, natomiast największy wzrost zaszedł w zakresie niedoboru talentów i technologiach. Marka atrakcyjnego pracodawcy ułatwia przyciągnięcie i zatrzymanie talentów oraz specjalistów o kluczowych dla firmy kompetencjach. Dlatego skuteczny EB to „długoterminowa strategia przyciągania, zaangażowania i zatrzymania najbardziej utalentowanych pracowników w organizacji" " . Właściwe funkcjonowanie strategii to nie tylko jej opracowanie, ale również wdrażanie, regularne analizowanie zmian i otoczenia, reagowanie na te zmiany, ocena efektów własnych działań. Kwestia technologii to wyzwanie dla działów odpowiedzial-

\footnotetext{
${ }^{4}$ P. Zaręba, CSR na firmowym gruncie, „Personel i Zarządzanie” 2014/4, s. 33.

${ }^{5}$ M. Armstrong, Strategiczne zarzadzanie zasobami ludzkimi, Oficyna Wolters Kluwer Business, Warszawa 2010, s. 35 .

${ }^{6}$ Badanie Employer Branding $w$ Polsce, przeprowadzane przez HRM Institute od 2012 roku, jest jedynym kompleksowym badaniem, analizującym działania employer brandingowe pracodawców w Polsce.

${ }^{7}$ A. Macnar, Moc employer brandingu - jak zbudować skuteczna markę pracodawcy?, „Personel i Zarządzanie” $317 / 8$ (2016), s. 13
} 
nych za zarządzanie zasobami ludzkimi, gdyż są to działy najsłabiej zinformatyzowane i wyposażone w nowe technologie.

Odpowiedzialność za tworzenie strategii EB w ponad 50\% firm przypada na dział personalny (w roku 2012 było to prawie 90\%), po około 10\% na dział marketingu, dział employer brandingu lub zarząd oraz około 5-7\% na dział komunikacji zewnętrznej lub dział komunikacji wewnętrznej. O potrzebie EB świadczyć może fakt, że w raporcie za 2012 r. w ogóle nie figurowała komórka EB, w latach 2013-2014 funkcjonowała w około $5 \%$ ankietowanych firm, obecnie jest to $7 \%{ }^{8}$.

Najważniejsze elementy wspomagające strategię EB to między innymi:

- proces rekrutacyjny - od budowania unikatowych, zróżnicowanych ofert pracy aż po odpowiednie podziękowanie kandydatowi, który nie przeszedł do następnego etapu rekrutacji, wraz z umotywowaniem decyzji, interesujące; unikatowa oferta (obietnicy) pracodawcy dla potencjalnego pracownika (EVP, employment value proposition) zbiór wartości i skojarzeń, które mają pozytywnie oddziaływać na grupę docelową kandydatów;

- procesy onboardingu (adaptacyjne) - adaptacja i wdrożenie nowego pracownika; są one skierowane do nowych pracowników lub wracających do pracy po długiej nieobecności lub też pracujących na nowym stanowisku, na przykład w wyniku awansu wewnętrznego, przesunięć spowodowanych zmianami organizacyjnymi ${ }^{9}$. Mają tworzyć dobrą atmosferę w pracy i ułatwić szybkie i skuteczne zaadaptowanie się w organizacji. W ramach programu pracownik otrzymuje niezbędne informacje dotyczące firmy i stanowiska (podręczniki, spotkania wstępne i monitorujące postępy, wsparcie on-line, opiekuna), unika stresu związanego z niepewnością, może się skupić na swoich zadaniach i jest bardziej efektywny;

- indywidualne ścieżki kariery - określenie możliwych dróg przemieszczeń pionowych i poziomych między stanowiskami/rolami organizacyjnymi oraz zdefiniowanie wymagań kompetencyjnych i kwalifikacyjnych dla tych stanowisk, w celu planowania indywidualnych ścieżek rozwoju i awansu pracowników, działań rozwojowych i szkoleń;

- stosowanie work life balance - równowaga między pracą a życiem osobistym, która dla pokolenia Y i Z jest często ważniejsza niż uznanie i kariera; jej wdrożenie w życie wymaga od pracodawcy elastyczności, zaangażowania, odpowiedniego programu, ale głównie przekonania, że takie działania mają sens;

- zarządzanie wiekiem, współpraca międzypokoleniowa - dostosowania metod zarządzania personelem, ale również warunków i zasad rekrutacji do pokolenia baby boomers, X, Y i Z - to nie tylko kwestia zróżnicowanego wieku pracowników ale także ich mentalności i przyzwyczajeń, które wynikają $\mathrm{z}$ warunków ekonomicznospołecznych w których dorastali.

Employer branding to wymierne korzyści dla jednostki, która zdecyduje się na jego zaplanowanie i wdrożenie. Zostały one ujęte na rysunku 1. W obszarze zasobów ludzkich są nimi głównie: przyciągnięcie talentów oraz zmotywowany i zaangażowany zespół, co

\footnotetext{
${ }^{8}$ Na podstawie: Raport Employer Branding w Polsce 2012-2016, http://employerbrandingsummit.pl/raport-eb/ (dostęp: 20.08.2016)

${ }^{9}$ A. Piwowarczyk , Adaptacja nowego pracownika, „Controlling i Rachunkowość Zarządcza” 7/202 (2016), s. 32.
} 
skutkuje zmniejszeniem absencji i rotacji pracowniczej oraz zwiększeniem wydajności. Konsekwencją w obszarze finansowym jest poprawa wyników jednostki.

Rys. 1. Korzyści z zastosowania employer branding

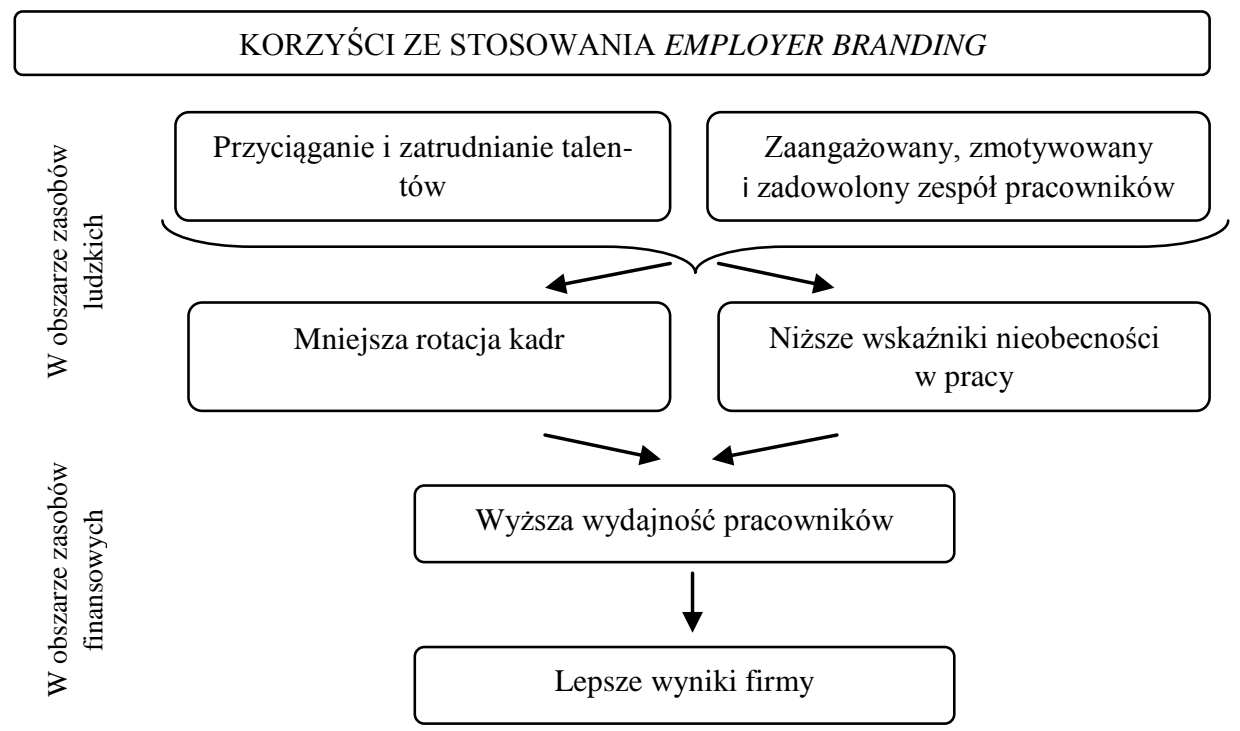

Źródło: opracowanie własne na podstawie: A. Macnar, Moc employer brandingu - jak zbudować skuteczna marke pracodawcy?, „Personel i Zarządzanie” 2016/8, s. 14.

Wypracowany wizerunek nie jest wartością stałą, zmienia się bowiem w zależności od:

- działań wewnętrznych: polityki HR i employer brandingowej, zmian personalnych;

- działań zewnętrznych: sytuacji rynkowej, działań konkurencji, wejścia nowego pokolenia na rynek.

W raporcie Employer Branding z 2016 roku pracodawcy mogli ocenić atrybuty marki pracodawcy i ich znaczenie dla pozyskiwania talentów do firmy. Wśród najważniejszych znalazły się: atmosfera w firmie i jej reputacja (po 88\%), tuż za nimi wskazano: politykę nagradzania i uznania pracowników (87\%) oraz ścieżkę kariery zawodowej (85\%). $\mathrm{Na}$ następnych pozycjach wymieniano: uznanie pracownika w pracy $(83 \%)$, politykę zarządzania ludźmi w firmie (79\%) i kulturę organizacyjną (78\%). Znaczenie CSR firmy w opinii pracodawców uzyskało $47 \%$. Z jednej strony stanowi to zachętę do zaproponowania w raportowaniu niefinansowym wskazanych atrybutów marki, takich jak polityka motywacyjna w firmie czy możliwe ścieżki kariery zawodowej, czyli poszerzenie informacji na temat praktyk i przywilejów pracowniczych skierowanej do potencjalnych pracowników. Z drugiej zaś powstaje pytanie, czy raportowanie CSR powinno odsłaniać wszelkie tajemnice przedsiębiorstwa? Czy nie zaszkodzi to jego konkurencyjności? Współcześnie kluczowym zasobem dającym przewagę konkurencyjną jest wiarygodna 
i transparentna informacja ${ }^{10}$. Z tym że na chwilę obecną zakres tej informacji, jeśli chodzi o raportowanie niefinansowe, jest dobrowolny, podobnie jak jej publikowanie.

\section{CZEMU I KOMU SLUŻA RAPORTY CSR?}

Raportowanie CSR wynika z koncepcji zrównoważonego rozwoju, zakładającej równowagę w trójkącie człowiek-ekonomia-środowisko. Istotą społecznej odpowiedzialności biznesu jest bardziej etyczne i odpowiedzialne, wielopłaszczyznowe postępowanie wobec grup społecznych i środowiska naturalnego, na które oddziałuje przez prowadzoną przez siebie działalność ${ }^{11}$. Zgodnie z normą ISO 26000 społeczna odpowiedzialność to zobowiązanie organizacji do włączania aspektów społecznych i środowiskowych w proces podejmowania decyzji oraz wzięcie odpowiedzialności za wpływ podejmowanych decyzji i aktywności na społeczeństwo i środowisko.

Komisja Europejska wcześniej definiowała CSR jako „koncepcję, zgodnie z którą przedsiębiorstwa dobrowolnie uwzględniają problematykę społeczną i środowiskową $\mathrm{w}$ swojej działalności gospodarczej i stosunkach z zainteresowanymi stronami, [...] która dotyczy podejmowanych przez nie działań wynikających z ich zobowiązań prawnych wobec społeczeństwa i środowiska oraz wykraczających poza nie"12. Według Odnowionej Strategii UE „CSR to odpowiedzialność przedsiębiorstw za ich wpływ na społeczeństwo. Poszanowanie dla mającego zastosowanie prawodawstwa, a także dla układów zbiorowych pomiędzy partnerami społecznymi, jest warunkiem wstępnym wypełniania zobowiązań wynikających z tej odpowiedzialności. [...] przedsiębiorstwa powinny dysponować mechanizmem integracji kwestii społecznych, środowiskowych, etycznych i związanych z prawami człowieka, jak i problemów konsumentów ze swoją działalnością oraz podstawową strategią, w ścisłej współpracy z zainteresowanymi stronami, w celu:

- maksymalizacji tworzenia wspólnych wartości dla ich właścicieli/udziałowców i innych zainteresowanych stron i społeczeństwa jako całości;

- rozpoznawania, zapobiegania i łagodzenia ich możliwych negatywnych skutków"13.

Raportowanie CSR nie jest obecnie obowiązkiem ${ }^{14}$, chociaż dla niektórych jednostek wkrótce się stanie. Według zatwierdzonej we wrześniu 2015 r. przez Radę Unii Europejskiej Dyrektywy 2014/95/UE o rachunkowości największe spółki, tzw. jednostki zainteresowania publicznego, będą miały obowiązek wykazania w sprawozdaniu z działalności istotnych informacji dotyczących kwestii środowiskowych, społecznych i pracowniczych, poszanowania praw człowieka oraz przeciwdziałania korupcji i łapownictwu.

\footnotetext{
${ }^{10}$ E. Walińska, B. Bek-Gaik, J. Gad, B. Rymkiewicz, Sprawozdawczość przedsiębiorstwa jako narzędzie komunikacji z otoczeniem. Wymiar finansowy i niefinansowy, Wydawnictwo Uniwersytetu Łódzkiego, Łódź 2015.

${ }^{11}$ R. Biadacz, Wyzwania XXI wieku a rachunkowość małych i średnich przedsiębiorstw, [w:] Współczesne problemy rachunkowości $w$ teorii i praktyce, red. H. Lelusz, R. Burchar, Wydawnictwo Uniwersytetu Warmińsko-Mazurskiego w Olsztynie, Olsztyn 2014, s. 58.

12 Zielona Księga. Promowanie europejskich ram odpowiedzialności społecznej przedsiębiorstw, Komisja Wspólnot Europejskich, COM(2001) 366.

${ }^{13}$ Odnowiona strategia UE na lata 2011-2014 dotycząca społecznej odpowiedzialności przedsiębiorstw, Komisja Wspólnot Europejskich, COM (2011) 681.

${ }^{14} \mathrm{Na}$ gruncie polskiego prawa bilansowego jednostki sporządzające sprawozdanie z działalności mają obowiązek, o ile jest to istotne dla oceny sytuacji jednostki, załączyć informacje dotyczące zagadnień środowiska naturalnego i zatrudnienia (Ustawa o rachunkowości, art. 49, ust. 3). Z kolei Krajowy Standard Rachunkowości nr 9 „Sprawozdanie z działalności” podaje, że „,W przypadku niektórych jednostek celowa jest prezentacja w SzD wyników działalności w poszczególnych sferach rozwoju: ekonomicznej, środowiskowej i społecznej”.
} 
Raporty społeczne służą więc dobrowolnemu komunikowaniu się przedsiębiorstw $\mathrm{z}$ jego interesariuszami. O ile raporty finansowe są czytelne raczej dla wąskiego grona zainteresowanych, o tyle raporty niefinansowe $\mathrm{w}$ założeniu mają być informacją o firmie dla: pracowników, kontrahentów, partnerów biznesowych, konkurencji, społeczności lokalnych, władz lokalnych, organizacji pozarządowych, organizacji konsumenckich, udziałowców, mediów, a także na przykład dla organizacji studenckich i absolwentów. Spełnią one swoją funkcję, jeśli będą szczerą formą dialogu z interesariuszami, nie tylko subiektywnym przedstawianiem swoich dokonań czy akcji charytatywnych. Społeczna odpowiedzialność biznesu nie może być jedynie kampanią wizerunkową, ponieważ wtedy staje się „zasłoną dymną" dla niechlubnych działań przedsiębiorstwa. Wyselekcjonowane dane w raportach społecznych w dowolnie opracowanej formie stają się, bez opracowanych standardów, laurką przedsiębiorstwa wystawioną samemu sobie. Dlatego dla zwiększenia wiarygodności i porównywalności danych wskazana byłaby standaryzacja uregulowań raportowania niefinansowego ${ }^{15}$.

Samelak stwierdza, że organizacja powinna rozliczać się z wpływu swoich decyzji i działalności na społeczeństwo, środowisko i gospodarkę, szczególnie z istotnych negatywnych konsekwencji, zgodnie z zasadą transparentności i przejrzystości ${ }^{16}$.

Istotne jest, aby działania w obszarze z CSR były związane z profilem działalności przedsiębiorstwa, na przykład jeśli degraduje ono środowisko naturalne ze względu na branżę, w jakiej działa to, choć w pewnym stopniu powinno rekompensować poczynione przez siebie szkody w tym obszarze czy niepożądane dla społeczeństwa skutki jego aktywności. Inne wyzwania stoją przed bankiem, rafinerią czy hipermarketem. Dlatego tak cenne są inicjatywy sektorowe i branżowe.

\section{RAPORTOWANIE CSR A BUDOWANIE WIZERUNKU PRACODAWCY W POLSCE}

Budowanie wizerunku pracodawcy jest szczególnie ważne dla zarządzających kapitałem ludzkim. Dlatego warte przytoczenia w tym aspekcie są zaobserwowane, pozytywne konsekwencje raportowania CSR między innymi:

- edukowanie pracowników, budowanie lojalności, zwiększanie efektywności pracy;

- budowanie zaufania i wiarygodności;

- poprawa reputacji, wizerunku firmy;

- zwiększenie przewagi konkurencyjnej ${ }^{17}$.

Jeśli są to efekty podjętych działań w obszarze CSR i istnieje możliwość poinformowania o tym swoich interesariuszy - obecnych i potencjalnych pracowników, to nie jest to tylko nowa odmiana marketingu czy filantropia.

Mimo popularności koncepcji społecznej odpowiedzialności raportowanie społeczne nie jest w Polsce tak powszechne Fundacja CSR.PL w roku 2015 sprawdziła 227 firm w Polsce $^{18}$ o największej skali oddziaływania. Wcielając się w rolę interesariuszy, którzy poszu-

\footnotetext{
${ }^{15}$ Więcej: J. Rubik, Wytyczne i uregulowania raportowania społecznej odpowiedzialności, „Prace Naukowe UE we Wrocławiu" 2016/442.

${ }^{16}$ J. Samelak, Zintegrowane sprawozdanie przedsiębiorstwa społecznie odpowiedzialnego, Wydawnictwo UE w Poznaniu, Poznań 2013, s. 44.

${ }^{17}$ Roszkowska P., Rewolucja w raportowaniu biznesowym, Difin, Warszawa 2011, s. 92-94.

${ }^{18}$ Kryteria wyboru firm do badania były następujące: najwyższe przychody, wielkość zatrudnienia oraz znaczenie firm dla społeczeństwa. Pod uwagę - oprócz znanych z różnych rankingów CSR branż - wzięto także spe-
} 
kują informacji o zrównoważonym rozwoju na stronach internetowych, analizowano między innymi, czy przedsiębiorstwa prowadzą politykę CSR, czy publikują swoje kodeksy etyczne, udostępniają kontakt do osób zajmujących się CSR, czy zamieszczają sprawozdania z pozafinansowej działalności, prowadzą politykę dotyczącą przestrzegania praw człowieka i dialogu z interesariuszami. Raport z monitoringu społecznej odpowiedzialności największych polskich firm sporządzony w 2015 r. przez Fundację Centrum CSR.pl został przedstawiony w tabeli 1 .

Tabela 1. Raport z monitoringu społecznej odpowiedzialności biznesu (CSR, corporate social responsibility) największych polskich firm sporządzony w 2015 roku przez Fundację Centrum CSR.pl

\begin{tabular}{|c|c|c|c|c|c|c|c|c|c|c|c|c|c|}
\hline Branża & 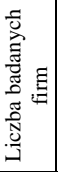 & 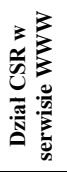 & 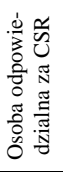 & 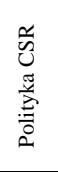 & 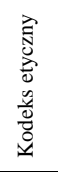 & 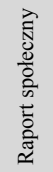 & 원 & 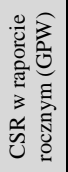 & 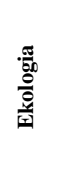 & 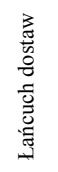 & 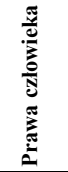 & 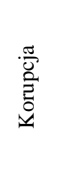 & 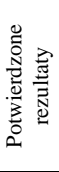 \\
\hline \multirow{2}{*}{ AGD/RTV } & 12 & 6 & 1 & 4 & 4 & 0 & 0 & 0 & 8 & 4 & 6 & 4 & 2 \\
\hline & & $50 \%$ & $8 \%$ & $33 \%$ & $33 \%$ & $0 \%$ & $0 \%$ & $0 \%$ & $67 \%$ & $33 \%$ & $50 \%$ & $33 \%$ & $17 \%$ \\
\hline \multirow[t]{2}{*}{ Budownictwo } & 13 & 8 & 2 & 5 & 3 & 1 & 1 & 1 & 8 & 3 & 5 & 4 & 3 \\
\hline & & $62 \%$ & $15 \%$ & $38 \%$ & $23 \%$ & $8 \%$ & $8 \%$ & $8 \%$ & $62 \%$ & $23 \%$ & $38 \%$ & $31 \%$ & $23 \%$ \\
\hline \multirow[t]{2}{*}{ Finanse } & 17 & 17 & 11 & 13 & 14 & 7 & 7 & 12 & 15 & 11 & 17 & 15 & 14 \\
\hline & & $100 \%$ & $65 \%$ & $76 \%$ & $82 \%$ & $41 \%$ & $41 \%$ & $71 \%$ & $88 \%$ & $65 \%$ & $100 \%$ & $88 \%$ & $82 \%$ \\
\hline \multirow[t]{2}{*}{ Handel } & 21 & 13 & 3 & 8 & 5 & 3 & 3 & 1 & 14 & 10 & 10 & 5 & 6 \\
\hline & & $62 \%$ & $14 \%$ & $38 \%$ & $24 \%$ & $14 \%$ & $14 \%$ & $5 \%$ & $67 \%$ & $48 \%$ & $48 \%$ & $24 \%$ & $29 \%$ \\
\hline \multirow[t]{2}{*}{$\begin{array}{l}\text { Horeca, sprzątanie, } \\
\text { ochrona, agencje pracy }\end{array}$} & 21 & 11 & 3 & 4 & 6 & 1 & 1 & 0 & 9 & 4 & 10 & 5 & 6 \\
\hline & & $52 \%$ & $14 \%$ & $19 \%$ & $29 \%$ & $5 \%$ & $5 \%$ & $0 \%$ & $43 \%$ & $19 \%$ & $48 \%$ & $24 \%$ & $29 \%$ \\
\hline \multirow[t]{2}{*}{ Media, komunikacja i IT } & 13 & 13 & 4 & 9 & 6 & 3 & 3 & 4 & 9 & 4 & 10 & 6 & 3 \\
\hline & & $100 \%$ & $31 \%$ & $69 \%$ & $46 \%$ & $23 \%$ & $23 \%$ & $31 \%$ & $69 \%$ & $31 \%$ & $77 \%$ & $46 \%$ & $23 \%$ \\
\hline \multirow[t]{2}{*}{ Moda i tekstylia } & 10 & 4 & 1 & 2 & 1 & 0 & 0 & 1 & 3 & 1 & 3 & 0 & 1 \\
\hline & & $40 \%$ & $10 \%$ & $20 \%$ & $10 \%$ & $0 \%$ & $0 \%$ & $10 \%$ & $30 \%$ & $10 \%$ & $30 \%$ & $0 \%$ & $10 \%$ \\
\hline \multirow[t]{2}{*}{ Przemysł chemiczny } & 11 & 8 & 2 & 8 & 5 & 1 & 1 & 3 & 9 & 5 & 7 & 5 & 3 \\
\hline & & $73 \%$ & $18 \%$ & $73 \%$ & $45 \%$ & $9 \%$ & $9 \%$ & $27 \%$ & $82 \%$ & $45 \%$ & $64 \%$ & $45 \%$ & $27 \%$ \\
\hline \multirow[t]{2}{*}{$\begin{array}{l}\text { Przemysł drzewny i } \\
\text { papierniczy }\end{array}$} & 10 & 8 & 2 & 5 & 3 & 1 & 1 & 1 & 9 & 4 & 6 & 4 & 3 \\
\hline & & $80 \%$ & $20 \%$ & $50 \%$ & $30 \%$ & $10 \%$ & $10 \%$ & $10 \%$ & $90 \%$ & $40 \%$ & $60 \%$ & $40 \%$ & $30 \%$ \\
\hline \multirow[t]{2}{*}{$\begin{array}{l}\text { Przemysł metalowy, } \\
\text { maszynowy i samocho- } \\
\text { dowy }\end{array}$} & 19 & 12 & 5 & 9 & 7 & 2 & 2 & 2 & 15 & 9 & 12 & 7 & 5 \\
\hline & & $63 \%$ & $26 \%$ & $47 \%$ & $37 \%$ & $11 \%$ & $11 \%$ & $11 \%$ & $79 \%$ & $47 \%$ & $63 \%$ & $37 \%$ & $26 \%$ \\
\hline \multirow[t]{2}{*}{ Przemysł spożywczy } & 15 & 9 & 1 & 6 & 1 & 1 & 1 & 1 & 10 & 4 & 4 & 2 & 3 \\
\hline & & $60 \%$ & $7 \%$ & $40 \%$ & $7 \%$ & $7 \%$ & $7 \%$ & $7 \%$ & $67 \%$ & $27 \%$ & $27 \%$ & $13 \%$ & $20 \%$ \\
\hline \multirow[t]{2}{*}{ Służba zdrowia i farmacja } & 10 & 9 & 5 & 6 & 4 & 2 & 2 & 1 & 7 & 4 & 7 & 5 & 5 \\
\hline & & $90 \%$ & $50 \%$ & $60 \%$ & $40 \%$ & $20 \%$ & $20 \%$ & $10 \%$ & $70 \%$ & $40 \%$ & $70 \%$ & $50 \%$ & $50 \%$ \\
\hline
\end{tabular}

cjalne strefy ekonomiczne czy spółki świadczące usługi komunalne. Badanie było realizowane przez niezależną, niepowiązaną z biznesem organizację, która samodzielnie wybrała monitorowane podmioty, nie pytając firm o zgodę. 


\begin{tabular}{|c|c|c|c|c|c|c|c|c|c|c|c|c|c|}
\hline Branża & 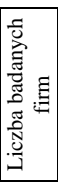 & 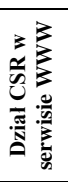 & 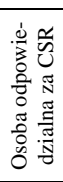 & 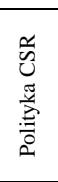 & 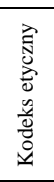 & 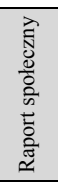 & 总 & 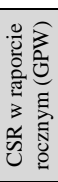 & 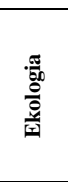 & 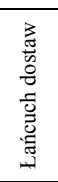 & 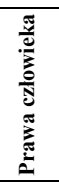 & $\begin{array}{l}\frac{\pi}{\sigma} \\
\cong \\
\vdots \\
0 \\
0\end{array}$ & 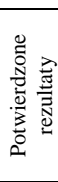 \\
\hline $\begin{array}{l}\text { Specjalne strefy ekono- } \\
\text { miczne }\end{array}$ & 14 & 3 & 1 & 0 & 0 & 0 & 0 & 0 & 1 & 0 & 1 & 0 & 3 \\
\hline & & $21 \%$ & $7 \%$ & $0 \%$ & $0 \%$ & $0 \%$ & $0 \%$ & $0 \%$ & $7 \%$ & $0 \%$ & $7 \%$ & $0 \%$ & $21 \%$ \\
\hline $\begin{array}{l}\text { Surowce, paliwa i } \\
\text { energetyka }\end{array}$ & 13 & 12 & 7 & 12 & 9 & 11 & 9 & 9 & 13 & 10 & 11 & 9 & 8 \\
\hline & & $92 \%$ & $54 \%$ & $92 \%$ & $69 \%$ & $85 \%$ & $69 \%$ & $69 \%$ & $100 \%$ & $77 \%$ & $85 \%$ & $69 \%$ & $62 \%$ \\
\hline Transport i logistyka & 13 & 10 & 3 & 7 & 4 & 2 & 2 & 2 & 11 & 6 & 11 & 5 & 5 \\
\hline & & $77 \%$ & $23 \%$ & $54 \%$ & $31 \%$ & $15 \%$ & $15 \%$ & $15 \%$ & $85 \%$ & $46 \%$ & $85 \%$ & $38 \%$ & $38 \%$ \\
\hline Usługi komunalne & 15 & 6 & 0 & 5 & 2 & 0 & 0 & 0 & 13 & 1 & 5 & 2 & 1 \\
\hline & & $40 \%$ & $0 \%$ & $33 \%$ & $13 \%$ & $0 \%$ & $0 \%$ & $0 \%$ & $87 \%$ & $7 \%$ & $33 \%$ & $13 \%$ & $7 \%$ \\
\hline Razem & 227 & 149 & 51 & 103 & 74 & 35 & 33 & 38 & 154 & 80 & 125 & 78 & 71 \\
\hline
\end{tabular}

GRI - raporty odpowiedzialnego biznesu i zrównoważonego rozwoju firm pogrubiona czcionka - najbardziej popularne obszary i branże w raportowaniu społecznym; szare pole - najbardziej ,zaniedbane” obszary i branże w raportowaniu społecznym

Źrodło: opracowanie własne na podstawie: Raport z monitoringu społecznej odpowiedzialności największych polskich firm. Teoria a praktyka, Fundacja Centrum CSR.PL, 2015, http://www.centrumcsr.pl/raporty-i-publikacje/ (dostęp: 28.08.2016).

$\mathrm{Z}$ raportu wynika, że najczęściej występujące obszary powiązane z CSR w polskich przedsiębiorstwach to informacje o ekologii (67\%) i prawach człowieka (55\%). Świadczy to o dużej świadomości firm w kwestiach ekologicznych i społecznych. Natomiast na podstawie badania można również stwierdzić, że $66 \%$ firm umieściło dział CSR w serwisie WWW, ale niestety tylko $15 \%$ zdecydowało się na raportowanie CSR (35 firm z grupy badawczej podaje do publicznej wiadomości swoje raporty społeczne, a 38 spółek ujmuje kwestie CSR w raportach rocznych).

Z punktu widzenia EB wyniki te oznaczają, że niewiele jednostek uważa CSR za istotne narzędzie wspomagające strategię tworzenia wizerunku pracodawcy, co potwierdza wspomniany wcześniej Raport EB z 2016 r. w zakresie atrybutów marki pracodawcy. Na podstawie tego badania można stwierdzić, że $27 \%$ firm nie znajduje właściwych kandydatów do pracy, bo wizerunek jednostki nie jest wystarczająco atrakcyjny, a 12\% badanych podmiotów przyznaje, że powinno zainwestować w zewnętrzne komunikowanie marki przedsiębiorcy.

Zdaniem Autorów jednym z narzędzi do komunikowania marki może stać się raport społecznej odpowiedzialności. Należy przy tym zauważyć, że z grupy 35 firm raportujących społecznie (tab. 1) 9 firm znalazło się w grupie Top Employers (edycja 2016) ${ }^{19}$, czyli najlepszych pracodawców. Trudno w tym zakresie stwierdzić ścisłą zależność, można jednak zauważyć, że raportowanie społeczne może wspomagać tworzenie marki pracodawcy.

\footnotetext{
${ }^{19}$ Certyfikat Top Employers jest przyznawany wyłącznie organizacjom, których oferta dla pracownika spełnia najwyższe standardy. Pierwszym krokiem w procesie certyfikacji jest wypełnienie przez firmę Kwestionariusza najlepszych praktyk HR: wszechstronna analiza obszaru HRM. Badanie dokładnie ocenia zarządzanie zasobami ludzkimi i warunki pracy w organizacji: http://www.top-employers.com/pl/ (dostęp: 29.10.2016).
} 


\section{PODSUMOWANIE}

Temat CSR został już dość wyczerpująco przedstawiony w literaturze, dlatego w artykule ograniczono się tylko do najważniejszych z nim związanych kwestii. Natomiast EB wymagałby szerszego omówienia, niż pozwalają na to ramy opracowania. Artykuł stanowi jedynie przyczynek do dyskusji nad powiązaniami między polityką personalną, szeroko pojętym HRM, w tym tworzeniem strategii wizerunkowej przedsiębiorstwa, a koncepcją społecznej odpowiedzialności i jej raportowaniem. Prawa i przywileje pracowników są wizytówką przedsiębiorstwa, a informowanie o nich w raportach społecznych stanowi dziś, zdaniem Autorów, czynność niezbędną dla employer branding, choć nie do końca docenianą przez pracodawców. Zgodnie $z$ teorią interesariuszy przedsiębiorstwa powinny równoważyć oczekiwania interesariuszy oraz korzyści osiągane przez przedsiębiorstwo w wyniku współpracy z nimi ${ }^{20}$. Interesariusze, jakimi są obecni i potencjalni pracownicy, oczekują innej informacji niż ta o respektowaniu praw człowieka i pracownika czy o równych szansach w zatrudnieniu, są to bowiem kwestie oczywiste, podlegające regulacjom prawnym. Pracowników interesują dodatkowa, unikatowa oferta i takie działania jednostki, które przyczynią się nie tylko do zapewnienia ich bytu, ale również ich satysfakcji z pracy, rozwoju i doskonalenia.

\section{LITERATURA}

[1] Armstrong M., Strategiczne zarzadzanie zasobami ludzkimi, Oficyna Wolters Kluwer Business, Warszawa 2010.

[2] Biadacz R., Wyzwania XXI wieku a rachunkowość matych i średnich przedsiębiorstw, [w:] Współczesne problemy rachunkowości w teorii i praktyce, red. H. Lelusz i R. Burchar, Wydawnictwo Uniwersytetu Warmińsko-Mazurskiego w Olsztynie, Olsztyn 2014.

[3] http://top-employers.com/pl/

[4] http://hrstandard.pl/2016/11/02/najlepszy-pracodawca-2016-wyniki/

[5] http://kariera.forbes.pl/najatrakcyjniejsi-pracodawcy-w-polsce-2015, artykuly,196866,1,1.html

[6] Kaputa J., Raportowanie zrównoważonego rozwoju jako wyzwanie dla przedsiębiorstw XXI wieku, „Zarządzanie i Finanse” 11/1 (2013), s. 113-127, http://jmf.wzr.pl/pim/2013_1_2_8.pdf (dostęp: 10.02.2016).

[7] Łada M., Kozarkiewicz A. Rachunkowość zarządcza - dwa wymiary prowadzenia badań naukowych, „Studia Oeconomica Posnaniensia” 266/2 (2014).

[8] Macnar A., Moc employer brandingu - jak zbudować skuteczna markę pracodawcy?, „Personel i Zarządzanie" 2016/8.

[9] Odnowiona strategia UE na lata 2011-2014 dotyczaca społecznej odpowiedzialności przedsiębiorstw, Komisja Wspólnot Europejskich, COM, 2011, 68.

[10] Piwowarczyk A., Adaptacja nowego pracownika, „Controlling i Rachunkowość Zarządcza” 202/7 (2016).

[11] Raport Employer Branding w Polsce 2012-2016, http://employerbrandingsummit.pl/raporteb/ (dostęp: 20.08.2016).

[12] Raport z monitoringu spolecznej odpowiedzialności największych polskich firm. Teoria a praktyka, Fundacja Centrum CSR.PL, 2015, http://www.centrumcsr.pl/raporty-i-publikacje/ (dostęp: 28.08.2016)

[13] Roszkowska P., Rewolucja w raportowaniu biznesowym, Difin, Warszawa 2011.

[14] Rubik J., Wytyczne i uregulowania raportowania społecznej odpowiedzialności, „Prace Naukowe UE we Wrocławiu" 2016/442.

\footnotetext{
${ }^{20}$ M. Łada, A. Kozarkiewicz, Rachunkowość zarzadcza - dwa wymiary prowadzenia badań naukowych, „Studia Oeconomica Posnaniensia” 266/2 (2014), s. 45.
} 
[15] Samelak J., Zintegrowane sprawozdanie przedsiębiorstwa społecznie odpowiedzialnego, Wydawnictwo UE w Poznaniu, Poznań 2013.

[16] Walińska E., Bek-Gaik B., Gad J., Rymkiewicz B., Sprawozdawczość przedsiębiorstwa jako narzędzie komunikacji z otoczeniem. Wymiar finansowy i niefinansowy, Wydawnictwo Uniwersytetu Łódzkiego, Łódź 2015.

[17] Zaręba P., CSR na firmowym gruncie, „Personel i Zarządzanie” 2014/4.

[18] Zielona Księga. Promowanie europejskich ram odpowiedzialności społecznej przedsiębiorstw, Komisja Wspólnot Europejskich, COM 2001, 366.

\section{CSR REPORT IN CREATING EMPLOYER BRANDING}

The aim of this article is to point out the importance of non-financial reporting as an essential condition for building an employer brand strategy. In the article an analysis of literature, reports and case studies, existing in Polish reality, as well as their own observations were used. The management of company is focused on profit, growth, value. Companies have physical, financial and human resources to achieve these objectives. Priorities can be different but the importance of these resources cannot be underestimated. However, the article deals with the area of human capital, which are the employees. The labor market passes a few years a revolution in the market of employee, which means that more and more often and more boldly job candidates dictate their own terms, or at least have specific requirements and expectations. To keep up with the changes, in the areas of HR, companies form a strategy to build brand image and employer, addressed to potential and existing employees the so called "employer branding". In conjunction with the using of CSR it is not just a way of finding themselves among the best employers but also to gain a competitive advantage in the market, which has an impact on the financial results. CSR reports can help the company in building the image on the outside.

Keywords: building the employer brand, employer branding, CSR, non-financial reporting

DOI: 10.7862/rz.2016.mmr.19

Tekst złożono w redakcji: kwiecień 2016

Przyjęto do druku: wrzesień 2016 